\title{
Hasil Cetak Informasi Elektronik dan/atau Dokumen Elektronik Sebagai Alat Bukti Tindak Pidana Pencemaran Nama Baik Melalui Media Daring
}

\author{
Aris Hardinanto \\ Dosen Fakultas Hukum Universitas Trunojoyo Madura \\ aris@trunojoyo.ac.id
}

\begin{abstract}
Developments and changes in the world to be very fast as a result of advances in science and technology, especially transportation and communication technology have made various facilities to people's mobility. Development of information flows between countries can no longer be controlled by the government, so the role in controlling the population through social networking mobiltias. Such growth resulted in social change in communities around the world, across borders. The new type of crime as a negative impact on the development of information technology appears along with the development of information technology. Crime using information technology or computer media and the Internet are called computer related crime or cybercrime. Position evidence as substantive criminal law enforcement become the parameters a judge to decide a case. Law No. 11 Year 2008 on Information and Electronic Transactions provide space to print out electronic evidence in cybercrime as valid evidence. The printout electronic evidence electronic evidence as valid if it can be guaranteed authenticity. Thus the position of electronic evidence in cybercrime has strict criteria compared to conventional evidence. Methods of research in this journal using the approach of law (statute approach), the approach of the case (case approach) as well as a conceptual approach (conceptual approach)
\end{abstract}

Keywords: electronic evidence, cybercrime.

\begin{abstract}
Abstrak
Perkembangan dan perubahan dunia menjadi sangat cepat sebagai akibat dari kemajuan ilmu pengetahuan dan teknologi, terutama teknologi transportasi dan komunikasi telah membuat berbagai kemudahan terhadap mobilitas masyarakat. Arus perkembangan informasi antar negara tidak dapat lagi dikendalikan oleh pemerintah, sehingga peran dalam mengendalikan arus mobiltias penduduk melalui jejaring sosial. Pertumbuhan yang seperti ini mengakibatkan perubahan sosial di masyarakat seluruh dunia, lintas batas negara. Kejahatan jenis baru sebagai dampak negatif dari perkembangan teknologi informasi muncul seiring dengan perkembangan teknologi informasi. Kejahatan menggunakan media teknologi informasi atau komputer dan internet disebut computer related crime atau cybercrime. Kedudukan alat bukti sebagai penegak hukum pidana materiil menjadi parameter hakim untuk memutus suatu perkara. Undang-undang No. 11 Tahun 2008 tentang Informasi dan Transaksi Elektronik memberikan ruang terhadap hasil cetak alat bukti elektronik dalam cybercrime sebagai alat bukti yang sah. Hasil cetak alat bukti elektronik sah apabila alat bukti elektronik itu dapat dijamin keasliannya. Dengan demikian kedudukan alat bukti elektronik dalam cybercrime memiliki
\end{abstract}


kriteria yang ketat dibanding alat bukti konvensional. Metode penelitian dalam jurnal ini menggunakan pendekatan perundang-undangan (statute approach), pendekatan kasus (case approach) serta pendekatan konseptual (conceptual approach)

Kata kunci: alat bukti elektronik, cybercrime.

\section{Pendahuluan}

Satjipto Rahardjo berpendapat bahwa terdapat banyak alasan yang dapat dikemukakan sebagai penyebab timbulnya suatu perubahan di dalam masyarakat, tetapi perubahan dalam penerapan hasil-hasil teknologi modern dewasa ini banyak disebutsebut sebagai salah satu sebab terjadinya perubahan sosial. Perubahan sosial menyangkut berbagai aspek kehidupan seperti perubahan terhadap pola pikir, interaksi sosial, dan gaya hidup masyarakat (Satjipto Rahardjo, 1980 : 96).

Salah satu penyebab perubahan sosial itu adalah dengan dikembangkannya teknologi informasi secara global. Teknologi Informasi yang berkembang sangat pesat menghasilkan fasilitas internet yang memudahkan interaksi masyarakat. Sudarto berpendapat dengan teknologi yang berkembang, memunculkan ilmu-ilmu baru yang sebelumnya pernah terdengar, diantaranya: agogie, polemologie, cybernetica, dan ilmu tentang pengaturan dan komunikasi otomatis (Sudarto, $2011: 26$ ).

Perkembangan teknologi informasi membawa dampak positif dan negatif. Dampak positifnya adalah jika ilmu pengetahuan dan teknologi tersebut dapat dimanfaatkan untuk kesejahteraan masyarakat. Dampak negatif sebaliknya, ilmu pengetahun dan teknologi dimanfaatkan untuk menyengsarakan masyarakat (Nyoman Serikat Putra Jaya, 2010 : 89).

Ilmu hukum mendapat imbas dengan perkembangan teknologi informasi. Nyoman Serikat Putra Jaya berpendapat bahwa perkembangan ilmu pengetahuan dan teknologi mau tidak mau mempunyai dampak bagi perkembangan hukum pidana pada umumnya dan khususnya hukum acara pidana (Nyoman Serikat Putra Jaya, 2011 : 67). Hukum pidana merupakan aturan hukum yang mengikatkan kepada suatu perbuatan yang memenuhi syarat-syarat tertentu suatu akibat yang berupa pidana (Sudarto, 1990 : 9). Perkembangan teknologi dan informasi dalam hal ini, internet, memberikan cakrawala baru tentang 
hukum pidana yang berkaitan dengan pemanfaatan teknologi dan informasi, khususnya mengenai perkembangan kejahatan melalui sarana internet (selanjutnya cybercrime). Sebagai contoh dalam hal ini adalah perkembangan hukum pidana dalam menghadapi bentuk baru kejahatan komputer (computer crime). Menurut (Muladi, 1990 : 29) survei O.C.E.D (Organization for Economic Cooperation and Development) jenisjenis kejahatan komputer yang paling menonjol saat ini adalah: 1) Computer espionage and program piracy, 2) Fraud by computer manipulation, 3)Computer sabotage, 4) Unauthorized use of computers, 5) Unauthorized access to DP system

Kehadiran internet juga menimbulkan sebuah lingkungan baru yang dikenal dengan sebutan mayantara (Barda Nawawi Arief, 2006 : 5). Tindak pidana seperti yang diuraikan oleh Muladi di atas dalam penelitian ini termasuk kategori "unauthorized use of computers". Kompleksitas dari tindak pidana ini dalam perkembangan tidak hanya melibatkan komputer saja, tetapi berkaitan dengan jaringan komputer dan sarana pendukung teknologi informasi di internet, seperti server dan hosting domain.
Beberapa julukan juga diberikan kepada kejahatan ini seperti virtual space offence, hight tech crime, transnational crime, dan white collar crime. Menurut Volodymyr Golubev cybercrime merupakan bentuk baru dari perilaku anti sosial (Barda Nawawi Arief, 2006 : 1). Pengaturan mengenai kegiatan di internet membawa keuntungan dan kerugian. Keuntungannya adalah karena internet merupakan sumber informasi tanpa batas, mempunyai tarif relatif murah, dan membantu di bidang perdagangan. Kerugiannya adalah dapat terjadi missinformasi karena tidak ada sensor, sulit dilacak, pemborosan waktu yang tidak produktif, keamanan transaksi dan pelanggaran privacy (Agus Raharjo, 2002 : 215-216).

$$
\text { Urgensi penanggulangan }
$$
cybercrime sebagai kejahatan jenis baru terlihat dengan dibahasnya cybercrime ini pada kongres $\mathrm{PBB}$ kedelapan tentang computer related crime (Eight UN Congress on the Prevention of Crime and The Treatment of Offenders, 1991 : 141). Pada tanggal 19 September 2000 dalam paper berjudul "Cyber Crime" yang dibuat oleh Information Technology Association of Canada (ITAC) yang disampaikan pada “International Information Industry 
Congress (IIIC) 2000 Millenium

Congress" di Quebec yang menyatakan bahwa: "Cyber crime is a real and growing threat to economic and social development around the world. Information technology touches every aspect of human life and so can electronically enabled crime" (ITAC, 2000: 2).

Berdasarkan hal tersebut, cybercrime sebagai kejahatan modern perlu diantisipasi menggunakan pendekatan-pendekatan yang berbeda dari kejahatan konvensional. Perkembangan dunia teknologi dan informasi telah merubah paradigma masyarakat dari paradigma paper based menuju paradigma electronic based (Edmon Makarim, 2003 : 415). Tidak dapat dipungkiri bahwa penggunaan internet dewasa ini mempermudah bagi masyarakat maupun penyidik dalam melakukan investigasi khususnya mengenai kejahatan yang terjadi di ranah cyber. Penggunaan internet menimbulkan permasalahan baru terkait tentang penegakan hukum, khususnya penggunaan alat bukti. Pasal 5 dan 6 Undang-undang No. 11 Tahun 2008 tentang Informasi dan Transaksi Elektronik (selanjutnya disebut UU ITE) memberikan perluasan alat bukti, yaitu diakuinya alat bukti elektronik sebagai alat bukti yang sah dan hasil cetak alat bukti tersebut diakui keabsahannya jika dapat dijamin keasliannya. Dalam beberapa kasus, Penuntut Umum menggunakan hasil cetak dari informasi elektronik dan/atau dokumen elektronik sebagai alat bukti. Berdasarkan hal tersebut, permasalahan yang muncul adalah antara lain; 1) Bagaimana pengaturan tindak pidana pencemaran nama baik di dalam UU ITE?; 2) Bagaimana kedudukan hasil cetak informasi elektronik dan/atau dokumen elektronik berdasarkan ketentuan UU ITE?

\section{Metode Penelitian}

Pendekatan masalah yang akan digunakan adalah pendekatan perundang-undangan

(statute approach), pendekatan kasus (case approach) serta pendekatan konseptual (conceptual approach). Pendekatan perundang-undangan (statute approach), ialah suatu pendekatan yang dilakukan dengan menelaah peraturan perundangundangan dan regulasi yang berkaitan dengan isi hukum atau permasalahn yang sedang diteliti, adakah kesesuaian dan konsistensi antara undang-undang dan undang-undang lainnya, atau antara undang-undang 
dengan undang-undang dasar 1945, atau antara regulasi dengan undangundang. Pendekatan kasus (case approach), ialah suatu pendekatan dengan cara melakukan telaah terhadap kasus-kasus yang berkaitan dengan isu yang dihadapi yang telah menjadi putusan pengadilan. Sedangkan pendekatan pendekatan konseptual (conceptual approach) ialah suatu metode pendekatan dengan cara prinsip-prinsip hukum berupa pandangan para ahli hukum, doktrindoktrin hukum, serta secara eksplisit juga ditemukan pada konsep hukum yang ada pada aturan perundangundangan.

\section{Pembahasan}

Pembuktian adalah hal yang fundamental dalam hukum pidana karena menentukan dapat atau tidaknya seseorang dipidana. Menurut Al. Wisnubroto ( 2010 : 136-137) ada beberapa kendala dalam mengungkap kejahatan di dunia internet dalam tataran aplikasi penegakan hukum, terutama terkait dengan masalah pembuktian, diantaranya adalah: 1)

Keterbatasan pengetahuan kemampuan aparat penegak hukum dalam menangani kasus-kasus yang berkaitan dengan high technology. 2) Keterbatasan tersedianya fasilitas technology untuk mengungkap kasuskasus yang berkaitan dengan hightechnology; misalnya terbatasnya keberadaan laboratorium forensik komputer di Indonesia. 3) Peran saksi ahli (testimony expert) dalam proses pidana masih belum bisa dimanfaatkan secara optimal. 4) Rendahnya kesadaran korban untuk melaporkan kasus kriminal yang terjadi pada sistem keamanan komputernya, terutama kesediannya sebagai saksi utama.

Kendala-kendala mengenai pengungkapan cybercrime di Indonesia dapat disimpulkan terletak pada kemampuan sumber daya manusia dalam bidang hukum pembuktian.

Pembuktian dalam hukum acara pidana berbeda dengan pembuktian hukum acara perdata. Dalam hukum acara pidana pembuktian bersifat materiil yang mempunyai arti pembuktian sebenar-benarnya untuk memperoleh suatu kebenaran materiil, sedang dalam hukum acara perdata, kebenarannya adalah kebenaran yang bersifat formil. Terdapat 3 (tiga) teori sistem pembuktian yang ada; Pertama, sistem atau teori pembuktian berdasar undang-undang secara positif (positief wettelijke bewijs theorie), sistem pembuktian berdasar undang-undang 
secara positif ini berarti pembuktian yang didasarkan melulu kepada alatalat pembuktian yang disebut di dalam undang-undang. Dikatakan positif karena hanya didasarkan pada undangundang saja. Artinya jika telah terbukti suatu perbuatan sesuai dengan alat-alat bukti yang disebut oleh undang-undang, maka keyakinan hakim tidak diperlukan sama sekali. Teori ini berusaha menyingkirkan semua pertimbangan subyektif hakim dan mengikat hakim secara ketat menurut peraturan perundangundangan dengan pembuktian yang keras yang saat itu di Eropa berlakuknya asas inkisitor (inquisitor) dalam acara pidana.

Kedua, sistem atau teori pembuktian beradasarkan keyakinan hakim melulu, teori ini memungkinkan hakim menyebut apa saja yang menjadi dasar keyakinannya. Dahulu sistem pembuktian ini pernah dianut di Indonesia. Sistem ini memberi kebebasan kepada hakim terlalu besar sehingga sulit diawasi. Di samping itu terdakwa dan penasehat hukumnya sulit untuk melakukan dan membuat pembelaan. Dalam hal ini hakim dapat memidana terdakwa berdasarkan keyakinannya bahwa ia telah melakukan apa yang didakwakan;
Ketiga, sistem atau teori pembuktian berdasar keyakinan hakim atas alasan yang logis (la conviction rais onee), teori ini muncul sebagai jalan tengah atas kedua teori pembuktian sebelumnya. Menurut teori ini hakim dapat memutuskan seseorang berdasar keyakinannya, yang mana didasarkan kepada dasar-dasar pembuktian disertai dengan suatu kesimpulan yang mendasarkan pada peraturan pembuktian tertentu (Andi Hamzah, 1985 : 228-231).

Het Herzienne Indonesische Reglement (selanjutnya disebut HIR) dan KUHAP semuanya menganut sistem pembuktian berdasar undangundang secara negatif yang tertera di dalam Pasal 183 KUHAP dan Pasal 294 HIR. Menurut Wirjono Prodjodikoro untuk Indonesia, sistem pembuktian berdasar undang-undang sebaiknya dipertahankan beradasarkan 2 (dua) alasan, pertama, karena memang sudah selayaknya harus ada keyakinan hakim tentang kesalahan terdakwa untuk dapat menjatuhkan pemidanaan, kedua karena ada asas kemanfaatan yang mengikat hakim jika ada kaidah dan aturan dalam menyusun keyakinannya, agar ada patokan-patokan tertentu yang mengawal dalam melakukan acara 
pidana (WirjonoProdjodikoro, 1982 : 77).

Pembuktian sebuah hal yang fundamental dalam hukum pidana karena merupakan sarana untuk membuktikan ada atau tidaknya suatu peristiwa hukum di mana seseorang melakukan tindak pidana. Suatu peristiwa hukum belum tentu mengandung unsur tindak pidana, oleh karena itu dibutuhkan pembuktian untuk mengetahui suatu peristiwa hukum memuat suatu tindak pidana. Berdasarkan Pasal 183 KUHAP, "hakim dilarang menjatuhkan pidana kepada seorang kecuali apabila dengan sekurang-kurangnya dua alat bukti yang sah dan memperoleh keyakinan bahwa suatu tindak pidana benarbenar terjadi dan bahwa terdakwalah yang bersalah melakukannya".

KUHAP sendiri telah menentukan di dalam Pasal 184 yang menjadi alat bukti. Berdasarkan Pasal 184 KUHAP yang dapat dijadikan alat bukti yang sah adalah: keterangan saksi, keterangan ahli, surat, petunjuk, dan keterangan terdakwa, yang diuraikan sebagai berikut: Pertama, keterangan saksi, Pasal 1 angka 27 KUHAP dinyatakan keterangan saksi adalah salah satu alat bukti dalam perkara pidana yang berupa keterangan dari saksi mengenai suatu peristiwa pidana yang didengar sendiri, dilihat sendiri dan dialami sendiri dengan menyebut alasan dari pengetahuannya itu dan di dalam Pasal 185 ayat (1) keterangan saksi sebagai alat bukti ialah apa yang saksi nyatakan di sidang pengadilan. Ada sebuah kontroversi terhadap kesaksian de auditu atau hearsy evidence. Pasal 185 ayat (5) KUHAP memberikan penjelasan bahwa kesaksian de auditu tidak mempunyai kekuatan pembuktian sebagai alat bukti. Menurut KUHAP keterangan "satu saksi bukan saksi" hanya bisa dipakai pada pemeriksaan biasa dan pemeriksaan singkat, tidak berlaku bagi pemeriksaan cepat. Di dalam Pasal 310 HIR dahulu, hanya dikatakan bahwa keterangan saksi haruslah mengenai hal-hal yang dialami, dilihat atau didengar olehnya, sesuai dengan keterangan dari KUHAP, maka sejatinya kesaksian tersebut tidak dapat dipergunakan di dalam pengadilan, akan tetapi hakim boleh mendengarkannya walaupun tidak mempunyai nilai pembuktian tetapi dapat memperkuat keyakinan hakim yang bersumber kepada 2 (dua) alat bukti itu.

Adapun persyaratan menjadi saksi adalah di luar dari larangan menjadi saksi berikut: 1) Keluarga 
sedarah atau semanda dalam garis lurus ke atas atau ke bawah sampai derajat ketiga dari terdakwa atau yang bersama-sama sebagai terdakwa; 2) Saudara dari terdakwa atau yang bersama-sama sebagai terdakwa, saudara ibu atau saudara bapak, juga mereka yang mempunyai hubungan karena parkawinan dan anak-anak saudara terdakwa sampai derajat ketiga; 3) Suami atau isteri terdakwa maupun sudah bercerai atau yang bersama-sama sebagai terdakwa (Andi Hamzah, 1985 : 242).

Dengan demikian seorang saksi haruslah memenuhi kriteria melihat, mendengar, dan mengalami sendiri suatu tindak pidana dan tidak memiliki hubungan baik hubungan perkawinan maupun pertalian darah dengan terdakwa.

Kedua, keterangan ahli, keterangan ahli ini termuat di dalam Pasal 186 KUHAP yang berbunyi sebagai berikut, "Keterangan ahli ialah apa yang seorang ahli nyatakan di sidang pengadilan". Pengertian ahli sendiri tidak menemukan penjelasan apa-apa di dalam KUHAP. Pasal 186 hanya berbicara yang dimaksudkan dengan keterangan ahli ialah apa yang seorang ahli nyatakan di dalam persidangan. Pasal 1 angka 28 KUHAP hanya sekedar menyebutkan seseorang yang memiliki keahlian khusus. Ada beberapa pasal yang menyinggung siapa sajakah yang disebut dengan ahli seperti ahli yang mempunyai pengetahuan tentang surat palsu pada pasal 132 KUHAP, ahli kedokteran forensik pada Pasal 133 ayat (1) dan pasal 179 ayat (1) KUHAP, tetapi penyebutan tersebut tidak menyinggung kualifikasi siapa saja yang disebut ahli.

Dari keterangan yang diberikan di pengadilan terhadap sebuah perkara, maka setidak-tidaknya ahli dibedakan dalam beberapa jenis: 1) Ahli yang menerangkan sesuatu berdasarkan keahlian khusus untuk itu, 2) Ahli yang menerangkan semata-mata tentang kehalian khusus mengenai suatu hal yang berhubungan erat dengan perkara pidana tanpa melakukan pemeriksaan terlebih dahulu (Adami Chazawi, 2009 : 66.).

Seorang ahli tidak selalu ditentukan oleh adanya pendidikan formal khusus untuk bidang keahliannya, tetapi dalam bidang pekerjaan tertentu yang ditekuninya selama waktu tertentu yang cukup lama sangat mungkin menjadi ahli dibidang tersebut. Dengan demikian yang dimaksud dengan keterangan ahli adalah keterangan yang diberikan di dalam persidangan oleh seseorang 
karena pengetahuannya dalam disiplin ilmu tertentu.

Ketiga, SuratJenis surat di dalam Pasal 187 KUHAP sebagai berikut: 1) Berita acara dan surat lain dalam bentuk resmi yang dibuat oleh pejabat umum yang berwenang atau yang dibuat di hadapannya, yang memuat keterangan tentang kejadian atau keadaan yang didengar, dilihat atau yang dialaminya sendiri, disertai dengan alasan yang jelas dan tegas tentang keterangannya itu; 2) Surat yang dibuat menurut ketentuan peraturan perundang-undangan atau surat yang dibuat oleh pejabat mengenai hal yang termasuk dalam tata laksana yang menjadi tanggung jawabnya dan yang diperuntukkan bagi pembuktian sesuatu hal atau sesuatu keadaan. Surat dimaksud ialah: Pertama, surat keterangan dari seorang ahli yang memuat pendapat berdasarkan keahliannya mengenai sesuatu hal atau sesuatu keadaan yang diminta secara resmi dari padanya; Kedua, surat lain yang hanya dapat berlaku jika ada hubungannya dengan isi dari alat pembuktian yang lain.

KUHAP tidak banyak mengatur kriteria surat yang dijadikan alat bukti. Untuk menerangkan lebih lanjut mengenai keabsahan alat bukti surat, setidaknya dapat digunakan pendekatan: a) Formil: sebuah surat dapat dikatakan memiliki kekuatan pembuktian yang sempurna jika terpenuhi ketentuan formil dalam pembuatannya serta dibuat dan berisi keterangan resmi dari seorang pejabat berwenang dan surat tersebut dilaksanakan dalam sumpah jabatan. b) Materiil: nilai pembuktian surat tersebut adalah "bebas". Hakim dapat menilai surat tersebut asli atau tidaknya berdasarkan asas proses pemeriksaan dan asas keyakinan hakim (Edmon Makarim, 2005 : 438).

Pada Pasal 187 butir c KUHAP, mengatur penggabungan antara keterangan ahli dengan alat bukti surat. Contohnya adalah visum et repertum yang dikeluarkan oleh seorang dokter dalam memeriksa subyek hukum yang terkait dengan suatu tindak pidana.Berbeda dengan hukum perdata, terdapat pembagian jenis surat: a) akta: akta otentik, akta di bawah tangan. b) bukan akta.

Pada dasarnya surat yang termasuk pada alat bukti yang tertera d .i dalam pasal 187 huruf a adalah surat resmi yang dikeluarkan oleh pejabat yang berwenang untuk membuatnya. Syarat resmi dari sebuah surat yang dikeluarkan oleh seorang pejabat haruslah: 1) Keterangan tentang kejadian atau keadaan yang dilihat 
atau dialami pejabat itu sendiri. 2) Disertai alasan yang jelas dan tegas tentang keterangannya.

Pada Pasal 187 KUHAP huruf a dan b terdapat official akten berupa akta otentik atau akta jabatan, kemudian pada Pasal 187 huruf c surat yang didalamnya memuat keterangan ahli dan terakhir pada Pasal 187 huruf d mengenai surat yang sedang berhubungan dengan tindak pidana tersebut. Dengan demikian yang dapat dijadikan alat bukti di dalam persidangan adalah surat yang dikeluarkan oleh orang atau badan tertentu yang memiliki kewenangan.

Keempat, petunjuk, berdasarkan pada Pasal 181 ayat (1) KUHAP petunjuk adalah, "perbuatan, kejadian, atau keadaan, yang karena persesuaiannya, baik antara yang satu dengan yang lain, maupun dengan tindak pidana itu sendiri, menandakan bahwa yang telah terjadi suatu tindak pidana dan siapa pelakunya. Alat bukti petunjuk adalah sama dengan alat bukti pengamatan" (Edmon Makarim, 2005 : 254). Pada Pasal 188 ayat (3) KUHAP yang mengatakan bahwa penilaian atas kekuatan pembuktian dari suatu petunjuk dalam setiap keadaan tertentu dilakukan oleh hakim dengan arif dan bijaksana, setelah ia mengadakan pemeriksaan dengan penuh kecermatan dan keseksamaan berdasarkan nuraninya.Apa yang disebut pengamatan oleh hakim (eign waarneming van de rechter) harus dilakukan selama sidang, apa yang telah dialami atau diketahui oleh hakim sebelumnya tidak dapat dijadikan dasar pembuktian, kecuali kalau perbuatan atau peristiwa itu telah diketahui oleh khalayak ramai. Dengan demikian petunjuk adalah segala sesuatu yang menandakan suatu tindak pidana telah terjadi.

Kelima, keterangan terdakwa, pada Pasal 189 KUHAP yang dimaksud dengan keterangan terdakwa adalah "apa yang terdakwa nyatakan di sidang tentang perbuatan yang ia lakukan atau yang ia ketahui sendiri atau alami sendiri”. Keterangan tersebut meliputi: 1) Keterangan terdakwa yang diberikan di luar sidang dapat digunakan untuk membantu menemukan bukti di sidang, asalkan keterangan itu didukung oleh suatu alat bukti yang sah sepanjang mengenai hal yang didakwakan kepadanya; 2) Keterangan terdakwa hanya dapat digunakan terhadap dirinya sendiri; 3) Keterangan terdakwa saja tidak cukup untuk membuktikan bahwa ia bersalah melakukan perbuatan yang didakwakan kepadanya, melainkan 
harus disertai dengan alat bukti yang lain.

Kalau dibandingkan dengan ketentuan HIR, maka terdapat sebuah perbedaan fundamental, yaitu antara pengakuan terdakwa dengan keterangan terdakwa. KUHAP tidak menjelaskan perbedaan antara pengakuan terdakwa dengan keterangan terdakwa. Keterangan terdakwa tidaklah sama dengan pengakuan terdakwa di dalam HIR, karena pengakuan mempunyai syaratsyarat tersendiri, yaitu: (1) mengaku ia yang melakukan delik yang di dakwakan; (2) mengakui kesalahan yang dia perbuat ( Andi Hamzah, 1985 :255).

Terdapat sebuah perbedaan fundamental lainnya terkait antara pengakuan terdakwa dengan keterangan terdakwa. Keterangan terdakwa yang menyangkal dakwaan, tetapi membenarkan beberapa keadaan atau perbuatan yang menjurus kepada terbuktinya perbuatan sesuai alat bukti hal itu merupakan sebuah alat bukti. Dalam Memorie van Toelitching dijelaskan perubahan alat bukti dari pengakuan terdakwa kepada keterangan terdakwa membawa akibat kompleks, bahwa keterangan terdakwa itu kedudukannya hanyalah setara dengan keterangan saksi (Andi Hamzah, 1985 : 255).

Kekuatan pembuktian keterangan terdakwa adalah sebagai berikut: 1) Sifat dan nilai kekuatan pembuktian adalah sangat bebas, hakim tidak terikat pada alat bukti keterangan terdakwa. Dia bebas untuk menilai kebenaran. Hakim dapat menerima atau menyingkirkan sebagai alat bukti yang di dalamnya haruslah disertai dengan alasan-alasan yang dapat dipertanggungjawabkan; 2) Pada pembuktian keterangan terdakwa, hakim terikat dan tunduk pada Pasal 183 KUHAP yang berkaitan dengan beban minimun alat bukti; 3) Rangakain keterangan terdakwa tersebut harus memenuhi azas keyakinan seorang hakim (Edmon Makarim, 2003 : 445-446). Dengan demikian keterangan terdakwa dapat menjadi pertimbangan hakim dalam menjatuhkan putusan atas suatu perkara.

Selain dari ketentuan mengenai alat bukti yang ditentukan oleh KUHAP, terdapat barang bukti yang dijadikan dasar atas suatu peristiwa hukum yang memuat suatu tindak pidana. Menurut Edmon Makarim (2003 : 447), barang bukti atau corpus delictie adalah "barang mengenai mana tindak pidana dilakukan yaitu 
alat yang dipakai untuk melakukan suatu tindak pidana". Menurut Ade Ary Sam Indradi (2006 : 133) barang bukti adalah, "hasil serangkaian tindakan penyidik dalam penyitaan dan atau penggeledahan dan atau pemeriksaan surat untuk mengambil alih dan atau menyimpan dibawah kekuasaanya, terhadap benda bergerak atau tidak untuk kepentingan pembuktian dalam penyelidikan, penuntutan dan selanjutnya peradilan". Menurut Hari Sasangka dan Lily Rosita (2003 : 100), kegunaan barang bukti di dalam persidangan adalah "bagi hakim untuk menyandarkan keyakinannya". Dari beberapa keterangan sarjana hukum tersebut dapat disimpulkan bahwa barang bukti adalah barang yang memiliki keterkaitan langsung dalam suatu tindak pidana baik yang digunakan dalam tindak pidana maupun yang diperoleh dari tempat kejadian perkara.

Alat bukti di dalam KUHAP tidak mencantumkan adanya alat bukti elektronik, yang di dalamnya berupa informasi elektrtonik dan/atau dokumen elektronik. Berdasarkan ketentuan Pasal 1 ayat (1) UU ITE yang dimaksud Informasi Elektronik adalah: "satu atau sekumpulan data elektronik, termasuk tetapi tidak terbatas pada tulisan, suara, gambar, peta, rancangan, foto, electronic data interchange (EDI), surat elektronik (electronic mail), telegram, teleks, telecopy atau sejenisnya, huruf, tanda, angka, Kode Akses, simbol, atau perforasi yang telah diolah yang memiliki arti atau dapat dipahami oleh orang yang mampu memahaminya."

Berdasarkan Pasal 1 ayat (5) UU ITE yang dimaksud sistem elektronik adalah serangkaian perangkat dan prosedur elektronik yang berfungsi mempersiapkan, mengumpulkan, mengolah, menganalisis, menyimpan, menampilkan, mengumumkan, mengirimkan, dan/atau menyebarkan Informasi Elektronik. Berdasarkan definisi tersebut, dapat simpulkan bahwa sumber dari informasi elektronik dalam pelaksanaannya atau dalam praktisnya melalui sebuah sistem elektronik.

Suatu informasi elektronik dan/atau dokumen elektronik menjadi akurat dan terpecaya bila sistem yang digunakan di dalam operasional dikeluarkan oleh sebuah sistem elektronik yang akurat dan terpecaya pula. Di dalam pelaksanaan sebuah sistem elektronik haruslah tersertifikasi sehingga informasi elektronik yang dikeluarkan darinya 
dapat dipercaya keberadaannya. Peranan alat bukti elektronik dalam cybercrime bukan merupakan sesuatu yang baru. Dalam mengungkap suatu alat bukti elektronik harus terlebih dahulu mengadakan pemeriksaan terhadap sistem elektronik yang digunakan karena erat kaitannya dengan keabsahan suatu sistem elektronik. Ada 2 (dua) hal yang dapat menjadi rujukan dalam mengungkap sebuah alat bukti elektronik, yaitu pola dalam sebuah tindak pidana cyber dan persesuaian dalam peristiwa hukum yang mengandung tindak pidana. Negara Inggris mengklasifikasikan kedudukan alat bukti elektronik seperti dikutip Edmon Makarim sebagai berikut: a) The Real Evidence Route, $b)$ The statutory route, c)The expert witness.

The Real evidence route merupakan alat bukti yang berdiri sendiri yang harus dapat diberikan jaminan bahwa suatu rekaman/salinan data berjalan sesuai dengan prosedur yang berlaku dengan pengesahan atas keabsahan suatu data (staturoty route) untuk disidangkan di pengadilan. Peranan ahli (expert witness) digunakan untuk memberikan keterangan dari pengetahuan dan pengalamannya ( Edmon Makarim, 2005 : 425). Di dalam kegiatan transaksi elektronik di beberapa negara, penggunaan alat bukti elektronik telah lama menjadi pembahasan yang cukup serius terkait di bidang hukum pembuktian. Michael Chissick dan Alistair Kelman seperti dikutip Dikdik M. Arief Manshur dan Elisatris Gultom menyatakan ada 3 (tiga) tipe pembuktian yang dibuat oleh komputer, yaitu: a) Real evidence, bukti nyata ini meliputi kalkulasi-kalkulasi atau analisaanalisa yang dibuat oleh komputer itu sendiri melalu aplikasi software dan penerima informasi dari devise lain. Bukti nyata ini muncul dari beberapa kondisi; b) Hearsay evidence, adalah dokumen-dokumen data yang diproduksi oleh komputer yang merupakan salinan dari informasi yang diberikan oleh manusia ke dalam komputer; c) Derived evidence, adalah informasi yang mengkombinasikan antara bukti nyata dengan informasi yang diberikan manusia kepada komputer dengan tujuan untuk membentuk suatu data yang tergabung ( Edmon Makarim, 2005 : 114).

Alat bukti elektronik dalam hukum pembuktian di Indonesia diberikan tempat tersendiri, di dalam Pasal 5 UU ITE: 1) Informasi 
Elektronik dan/atau Dokumen

Elektronik dan/atau hasil cetaknya merupakan alat bukti hukum yang sah;

2) Informasi elektronik dan/atau

Dokumen Elektronik dan/atau hasil cetaknya merupakan perluasan dari alat bukti yang sah sesuai dengan hukum acara yang berlaku di Indonesia; 3) Informasi Elektronik dan/atau Dokumen Elektronik dinyatakan sah apabila menggunakan Sistem Elektronik dinyatakan sah sesuai dengan ketentuan yang diatur dalam Undang-undang ini; 4) Ketentuan mengenai Informasi Elektronik dan/atau Dokumen Elektronik sebagaimana dimaksud pada poin satu di atas tidak berlaku untuk: a) Surat yang menurut UndangUndang harus dibuat dalam bentuk tertulis; $b$ )

Surat beserta dokumennya yang menurut Undang-undang harus dibuat dalam bentuk akta notaril atau akta yang dibuat oleh pejabat pembuat akta.
Pasal 6 UU ITE tentang alat bukti elektronik, ditentukan bahwa alat bukti elektronik tersebut dan hasil cetaknya haruslah dapat dijamin keasliannya:

"Dalam hal terdapat ketentuan lain selain yang diatur dalam Pasal 5 ayat (4) yang mensyaratkan bahwa suatu informasi harus berbentuk tertulis atau asli, Informasi Elektronik dan/atau Dokumen Elektronik dianggap sah sepanjang informasi yang tercantum di dalamnya dapat diakses, ditampilkan, dijamin keutuhannya, dan dapat dipertanggungjawabkan sehingga menerangkan suatu keadaan."

Pasal 5 ayat (1) menyatakan bahwa hasil cetak informasi dan/atau dokumen elektronik adalah alat bukti sah di dalam persidangan. Surat elektronik Prita Mulyasari dapat dijadikan alat bukti yang sah di persidangan jika dicetak berdasarkan surat elektronik elektronik dari akun pribadinya yang digunakan mengirim surat elektronik. Pasal 5 ayat (2) menyatakan bahwa informasi dan/atau dokumen elektronik dan/atau hasil cetaknya merupakan perluasan dari alat bukti konvesional di dalam KUHAP. Pasal 5 ayat (3) menyatakan bahwa informasi dan/atau dokumen elektronik adalah sah jika menggunakan sistem elektronik yang diatur dalam UU ITE ini. Pasal 5 ayat 

merupakan pengecualian informasi elektronik dan/atau dokumen elektronik yang dapat dijadikan sebagai alat bukti karena sifatnya yang harus tertulis .Pasal 6 UU ITE tersebut dapat disimpulkan bahwasannya alat bukti elektronik dan hasil cetaknya adalah sah secara hukum manakala dapat dijamin dan ditampilkan sesuai aslinya.

Sistem komputer tempat lalu lintas data merupakan berbagai rangkaian kombinasi komponen komputer yang membuatnya bekerja. Data yang umum diperoleh berasal dari komputer personal atau komputer desktop. Menjadikan hasil infomasi elektronik dan/atau dokumen elektronik sebagai alat bukti yang sah harus merujuk pada ketentuan Pasal 5 dan 6 UU ITE, hal ini merupakan konsekuensi dari ketentuan bahwa alat bukti elektronik haruslah dapat ditampilkan sesuai dengan aslinya dan metode yang sesuai untuk menjaga integritas alat bukti elektronik sebelum dicetak.

Kasus-kasus Pencemaran Nama Baik di Pengadilan Negeri Surabaya Beradasarkan penelitian yang dilakukan di Pengadilan Negeri Surabaya dan Pengadilan Negeri Bangkalan, terdapat 3 (tigA) kasus pencemaran nama baik melalui media daring, yaitu: Pertama; Putusan No. 509/PID/205/PN.SBY, putusan ini atas nama Terdakwa Ridwan Tunggal. Kasus ini berawal dari kiriman Blackberry Messenger (BBM) dari Blackberry type Torch 2 warna putih PIN 2A411270 nomor simcard 08986447577 milik Terdakwa kepada Laurensia Tunggal. Pesan BBM tersebut dibaca oleh kedua anak Laurensia. Sifat dari BBM yang berisi informasi elektronik memungkinkan isi pesan BBM dikategorikan sebagai alat bukti yang sah dan hasil cetaknya dapat diterima di Pengadilan.

Dalam pertimbangannya majelis hakim berpendapat dengan mengutip putusan Mahkamah Konstitusi Nomor 50/PUU-VI/2008 atas Judicial Review Pasal 27 ayat (3) jo Pasal 45 ayat (1) UU Nomor 11 Tahun 2008, terhadap unsur-unsur Pasal 27 ayat (3) UU ITE, yaitu mendistribusikan adalah perbuatan menyebarluaskan informasi atau dokumen elektronik melalui media elektronik, seperti web, mailing list; mentransmisikan adalah perbuatan mengiriimkan, memancarkan atau meneruskan informassi melalui perangkat telekomunikasi seperti handphone, email. membuat dapat diakses adalah perbuatan memberi peluang suatu 
informasi atau dokumen elektronik dapat diakses oleh orang lain, seperti membuat link atau memberitahu password suatu sistem elektronik. Dalam konteks kasus ini, hasil print pesan Blackberry Massanger (BBM) dapat dikategorikan hasil cetak dalam informasi elektronik dan/atau dokumen elektronik sebagaimana definisi informasi elektronik yang terdapat pada Pasal 1 ayat (1) UU RI Nomor 11 Tahun 2008 tentang ITE dan/atau sedefinisi dokumen elektronik yang terdapat pada Pasal 1 ayat (4) UU RI Nomor 11 Tahun 2008 tentang ITE.

Kedua, putusan tingkat banding dan telah memperoleh kekuatan hukum yang tetap atas Putusan No. 2334/Pid.B/2014/PN.SBY. Isi dari putusan ini memperkuat bahwa Terdakwa Ridwan Tunggal sengaja dan tanpa hak mendistribusikan dan/atau mentransmisikan dan/atau membuat dapat diaksesnya Informasi Elektronik dan/atau Dokumen Elektronik yang memiliki muatan penghinaan dan/atau pencemaran nama baik. Dasar pertimbangan hakim adalah setelah Majelis Hakim Pengadilan Tinggi mempelajari, meneliti dan mencermati secara seksama berkas perkara dan Salinan resmi putusan Pengadilan Negeri
Surabaya tanggal 16 maret 2015 Nomor : 2334/Pid.b/2014/PN.Sby; dan membaca serta memperhatikan dengan seksama Memori banding tertanggal 23 Maret 2015 yang diajukan oleh Jaksa Penuntut Umum dan Kontra memori banding tertanggal 24 April 2015 yang diajukan oleh terdakwa yang teryata tidak ada hal-hal yang baru yang perlu dipertimbangkan, maka Majelis Hakim Pengadilan Tinggi berpendapat bahwa pertimbangan hukum Majelis Hakin Tingkat pertama sudah tepat dan benar menurut hukum, sehingga pertimbangan tersebut dijadikan dasar pertimbangan sendiri oleh Majelis Hakim Tingkat Banding dalam memutus perkara yang dimintakan banding tersebut.

Ketiga, Putusan No. 2557/Pid.B/2015/PN.SBY, kasus ini bermula ketika terdakwa Andi Sukirman pada hari Kamis tanggal 14 Mei 2015 sekira jam 23.30 WIB mendistribusikan dan/atau mentransmisikan dan/atau membuat dapat diaksesnya Informasi Elektronik dan/atau Dokumen Elektronik yang memiliki muatan penghinaan dan/atau pencemaran nama baik. Perbuatan tersebut dilakukan dengan cara sebagai berikut; 
Pada mulanya Ira Rosita Adi Wijaya Liem Alias Kathy ke rumah saksi Kusnadi untuk menjemput anaknya kemudian terdakwa ia sedang dalam keadaan mabuk sambil membawa badik dan berteriak teriak ke arah saksi Ira Rosita Adi Wijaya Liem Alias Kathy dengan kata kata "Hei kamu suruh pelacur itu pulang" sempat menuduh saksi Ira Rosita Adi Wijaya Liem Alias Kathy tidur dengan saksi Kusnadi dan doyan "kontol", setelah itu terdakwa mencabut badik sambil mengacungkan kepada saksi Ira Rosita Adi Wijaya Liem Alias Kathy dan berkata "Hei pelacur lonthe kamu, gue tau siapa kamu, pulang kamu, dasar pelacur" dan selanjutnya dilerai orang.

Selanjutya terdakwa juga mengirimkan SMS ke nomor handphone saksi Ira Rosita Adi Wijaya Liem Alias Kathy yaitu 081234516776 dan 082140838393 yang isinya antara lain : a) Ket kamu tidak lebih pelacur udah aku buktikan; b) Udahlah jangan basa basi; c) Kamu itu tidak lebih ket tidak lebih dari pada lonte bagiku; d) Orang kampung udah curiga dan apalagi adikku membelaku; e) Dan apa lagi kakakku udah tidak senang lagi ama koko yang punya kantor; f) Makan kontol yang tidak punya pendidikan g)
Km itu ket tidak lebih dari pada pelacur aku udah ingatkan kamu... ok kamu tidak suka ama teo, tapi jangan ama temanku, koko itu siapa dan teo siapa .....!

Akibat dari perbuatan terdakwa, saksi Ira Rosita Adi Wijaya Liem Alias Kathy mengalami ketakutan dan trauma. Berdasarkan berita acara tekik krimiinalistik barang bukti No. lab : 3958/FKF/2015 oleh AKBP Drs. JOKO SISWANTO, M.T, Dkk yang memberikan kesimpulan sebagai berikut: 1) $0507 / 2015 / \mathrm{FKF}$ berupa 1(satu) unit mobile phone merk Nokia model 11 warna hitam dengan No.IMEI. 35670058066084, adalah benar ditemukan data pada mobile phone memory berupa 3 imbox text massege; 2) 0508/2015/FKF berupa 1(satu) unit sim card telkomsl dengan S/N. 62100340283893. Adalah benar ditemukan data pada sim card memory berupa 3 inbox tex massege; 3) 0509/2015/FKF berupa 1(satu) unit sim card XL dengan S/N. 8962116712157551122, adalah benar ditemukan data pada sim card memory berupa 4 deleted text massages; 4) 0507/2015/FKF berupa 1(satu) unit mobile phone merk Blackberry model Q10 warna hitam dengan IMEI 35670058066084, adalah benar ditemukan data pada mobile phone 
memory yang berupa (tangkapan layar) 152 contact dan 2 screenshot (tangkapan layar) isi text massages; 5) 0508/2015/FKF berupa 1(satu) unit sim card telkomsel tidak dapat terlihat adalah benar ditemukan pada sim card memory berupa 8 last dialed Number

Berdasarkan keterangan ahli Dendy Eka Puspawadi selaku ahli di bidang ITE, bahwa hasil capture short massage yang selanjutnya disebut print-out tersebut dijadikan sebagai alat bukti untuk pembuktian tindak pidana Pasal 27 ayat (3) UU ITE, karena hasil print out dikategorikan dalam informasi elektronik dan/atau dokumen elektronik. Dalam putusannya majelis hakim memutus terdakwa tidak bersalah karena surat dakwaan tidak memenuhi unsur formil yang ditentukan KUHAP.

Berdasarkan hal tersebut, aparat penegak hukum telah mengimplementasikan Pasal 5 dan Pasal 6 UU ITE karena menggunakan informasi elektronik dan/atau dokumen elektronik serta menjadikan hasil cetaknya sebagai alat bukti tindak pidana pencemaran nama baik.

\section{Kesimpulan}

Berdasarkan beberapa penjelasan dan uraian di atas dapat ditarik kesimpulan sebagai berikut:
1) Pengaturan tindak pidana pencemaran nama baik melalui media sosial sebenarnya telah diatur secara tegas dalam Pasal 27 ayat (3) jo. Pasal 45 ayat (1) UU ITE.

2) Pasal 5 dan Pasal 6 UU ITE juga mengatur mengenai perluasan alat bukti selain yang diatur di dalam KUHAP, yaitu hasil cetak dari informasi elektronik dan/atau dokumen elektronik adalah sah sebagai sebuah alat bukti. Dengan demikian, hasil cetak informasi elektronik dapat dijadikan atau memenuhi kretia sebagai alat bukti sah.

\section{Persantunan}

Penelitian ini dapat dilaksanakan atas bantuan Direktorat Jenderal Penguatan Riset dan Pengembangan Kementerian Riset, Teknologi, dan Pendidikan Tinggi melalui skim Penelitian Dosen Pemula tahun anggaran 2016.

\section{Daftar Rujukan}

A.S .Hornby (2000), Oxford Advanced Learner's Dictionary. Oxford: Oxford University Press.

Adami Chazawi (2006). Hukum Pembuktian Tindak Pidana Korupsi. Bandung, Penerbit P.T. Alumni. 
Agus Raharjo (2002), Cybercrime: Pemahaman dan Upaya Pencegahan Kejahatan Berteknologi. Bandung, Citra Aditya Bakti.

Al Wisnubroto (2010), Strategi Penanggulangan Kejahatan Telematika. Yogyakarta, Universitas Atma Jaya.

Andi Hamzah (1984), Pengantar Hukum Acara Pidana. Jakarta, Ghalia Indonesia.

Barda Nawawi Arief (2006), Tindak Pidana Mayantara: Perkembangan Kajian Cyber Crime di Indonesia, Jakarta, Rajagrafindo Persada.

Dikdik M. Arief Mansur dan Elisatris Gultom (2005), Cyber Law: Aspek Hukum Teknologi Informasi, Bandung, Refika Aditama.

Edmon Makarim (2000), Kompilasi Hukum Telematika, Jakarta, Rajagrafindo Persada.

Edmon Makarim (2007), Kompilasi Hukum Telematika, Jakarta, Rajawali Press.

Efa Lela Fakhriah (2009), Bukti Elektromik dalam Sistem Pembuktian Perdata. Bandung, Alumni.

Feri Sulianta (2008), Komputer Forensik, Jakarta, Elex Media Komputindo

Hari Sasangka dan Lily Rosita (2003), Hukum Pembuktian dalam Perkara Pidana, Bandung, Mandar Maju.
Muladi (1990), Proyeksi Hukum Pidana Materiil Indonesia di Masa Akan Datang Naskah Pidato Pengukuhan Guru Besar Fakultas Hukum Universitas Diponegoro. Semarang: Universitas Dipenegoro, Tanggal 23 Juli 1990.

Nyoman Serikat Putra Jaya. Bahan Kuliah Sistem Peradilan Pidana (Criminal Justice System). Semarang: Program Magister Ilmu Hukum UNDIP. Semester Ganjil 2009-2010

Kuliah Pembaharuan Hukum Pidana. Program Magister Ilmu Hukum UNDIP, UNSOED, dan UNTAG, Semester Genap 2010-2011.

Rahmat Rafiudin (2009), Internet Forensics: Investigasi SumberSumber Kejahatan Internet, Yogyakarta, Andi Publisher.

Satjipto Rahardjo (1980), Hukum dan Masyarakat, Bandung, Angkasa.

Sudarto (1990), Hukum Pidana 1, Semarang, Yayasan Sudarto. (198), Hukum dan Hukum Pidana, Bandung, Alumni.

\section{Peraturan Perundang-undangan}

Kitab Undang-Undang Hukum Pidana Kitab Undang-Undang Hukum Acara Pidana

Undang-undang Nomor 11 Tahun 2008 tentang Informasi dan Transaksi Elektronik

\section{Sumber Internet}

Digital Forensics Prita, http://samardi.files.wordpress.c 
om/2011/04/digital-foreniscs-

prita.pdf. diakses 22 Juni 2016.

Menyisir Jejak Forensik Digital,

http://www.infokomputer.com/

fitur/41-sekuriti/3618-

menyisir-jejak-forensik-

digital? showall=1. Diakses 22

Juni 2016.

Navnet History,

http://walthowe.com/navnet/his

tory.html. Diakses 22 Juni

2016. 